\title{
KEPASTIAN DALAM PENYELESAIAN HUKUM OLEH INDONESIA PADA DUMPING YANG DILAKUKAN REPUBLIK RAKYAT TIONGKOK DAN VIETNAM
}

\author{
Rahmadi Indra Tektona, Nuzulia Kumala Sari, Amru Hanifa Mukti \\ Fakultas Hukum, Universitas Jember \\ rahmadiindra@unej.ac.id
}

\begin{abstract}
Abstrak
Tujuan dari penulisan artikel ini adalah untuk mengetahui dan memahami upaya hukum yang dapat dilakukan Indonesia terhadap tindakan dumping yang dilakukan Tiongkok dan Vietnam dan untuk mengetahui dan memahami akibat hukum dari dumping yang dilakukan Tiongkok dan Vietnam terhadap Indonesia. Indonesia memiliki masalah peningkatan jumlah impor besi dan baja dari tahun ke tahun, akan tetapi impor dari Tiongkok dan Vietnam disorot berbeda oleh pemerintah karena mengalami peningkatan yang signifikan sehingga dicurigai melakukan dumping. Dengan begitu apa upaya hukum yang harus dilakukan terhadap dugaan dumping yang dilakukan Tiongkok dan Vietnam oleh lembaga-lembaga yang berwenang serta pihak-pihak terkait dan apa akibat hukumnya. Penelitian ini menggunakan metode penelitian yuridis normatif. Dumping saat ini belum diatur secara khusus dalam peraturan perundang-undangan di Indonesia. Antidumping Code 1994 menjadi dasar upaya yang dilakukan Indonesia terhadap Tiongkok dan Vietnam mengingat bahwa ketiga negara tersebut merupakan anggota dari World Trade Organization dengan General Agreement on Tariff and Trade. Komite Anti Dumping Indonesia (KADI) adalah lembaga yang diberikan kewenangan untuk melakukan penyelidikan dumping, baik secara offensive ataupun defensive yang dimulai berdasarkan inisiatif ataupun permohonan dari mayoritas industri dalam negeri barang sejenis. Apabila proses penyelidikan yang dilakukan oleh KADI terbukti ditemukan adanya dumping maka akan dikenakan sangsi berupa pengenaan Bea Masuk Anti Dumping sesuai besaran margin dumping, dan apabila tidak ditemukan atau margin deminimis maka proses penyelidikan dihentikan.
\end{abstract}

Kata kunci: Akibat Hukum; Dumping; Penyelesaian Hukum

\section{INDONESIAN LEGAL REMEDIES AGAINTS TIONGKOK AND VIETNAM DUMPING}

\begin{abstract}
The purpose of writing this article is to know and understand the legal efforts that Indonesia can make against dumping actions by China and Vietnam and to know and understand the legal consequences of dumping that China and Vietnam can make against Indonesia. Indonesia has a problem increasing the number of iron and steel imports from year to year, but imports from China and Vietnam are highlighted differently by the government because of a significant increase so suspected of dumping. Thus what legal efforts should be made against the alleged dumping carried out by China and Vietnam by the competent institutions and related parties and what are the legal consequences. This research uses normative juridical research methods. Dumping is currently not specifically regulated in the laws and regulations in Indonesia. The Antidumping Code 1994 became the basis of Indonesia's efforts against China and Vietnam considering that the three countries are members of the World Trade Organization with the General Agreement on Tariff and Trade. The Indonesian Anti Dumping Committee (KADI) is an institution that is given the authority to conduct dumping investigations, either offensively or defensively starting based on initiatives or requests from the majority of domestic industries of similar goods. If the investigation process conducted by KADI is proven to be found dumping, it will be subject to the imposition of Anti Dumping Duties
\end{abstract}


p-ISSN : 2541-2345, e-ISSN : 2580-8842

according to the amount of dumping margin, and if it is not found or deminimist margin then the investigation process is stopped.

Keywords: Dumping; Legal Effort; Consequence Of Law

\section{PENDAHULUAN}

\section{A. Latar Belakang}

Pendapat Radbruch, bahwa gagasan hukum sebagai landasan, tidak bisa formal. Sebaiknya ia terarah pada rechtsidee yaitu keadilan. Keadilan sebagai suatu cita, seperti yang ditunjukkan oleh Aristoteles, tidak dapat menagatakan lain kecuali "yang sama diperlakukan sama dan yang tidak sama diperlakukan tidak sama". Guna mengisi cita keadilan ini dengan isi yang kongret, kita harus menengok pada segi finalitasnya. Guna melengkapi keadilan dan finalitas itu diperlukan kepastian. Jadi bagi Radbruch, hukum memiliki 3 (tiga) aspek yaitu keadilan, finalitas dan kepastian. Aspek keadilan menunjuk pada "kesamaan hak didepan hukum":. Aspek finalitas menunjuk pada tujuan keadilan, yaitu memajukan kebaikan dalam diri manusia dan dan aspek ini menentukan isi hukum. Sedangkan aspek kepastian menunjuk pada jaminan bahwa hukum (yang berisi keadilan dan norma-norma yang memajukan kebaikan), benar-benar berfungsi sebagai peraturan yang ditaati. Boleh dikatakan, dua aspek yang disebut pertama merupakan kerangka ideal dari hukum. Sedangkan aspek ketiga (kepastian) merupakan kerangka operasional hukum . Tuntunan akan keadilan dan kepastian menurut Radbruch merupakan bagian-bagian yang tetap dari hukum. Sementara finalitas mengandung usur relativitas karena tujuan kedilan (sebagai isi hukum) untuk menumbuhkan nilai kebaikan bagi manusia, lebih sebagai nilai etis dalam hukum.

Nilai kebaikan bagi manusia dimaksud dapat dihubungkan dengan 3 (tiga) subyek yaitu individu, kolektivitas dan kebudayaan. Subyek individu merupakan hal pertama yang akan dimajukan kebaikannya. Hukum yang disusun untuk tujuan ini adalah individualitastis. Dalam sistem ini individu dan martabatnya tidak saja diagungkan tetapi juga diberi perlindungan khusus demi untuk mewujudkan kepentingan. Kebijakan protektif perdagangan kerap diambil pada pra abad ke-18 yang hanya berdampak pada sebagian orang (merkantilis) yang penguasaannya berada dibawah kaum pedagang dan penguasa politik, dan sebagian sisanya mendapat kemiskinan. ${ }^{1}$ Adam Smith berpendapat bahwa kebijakan tersebut menghambat dan menyebabkan kemunduran perdagangan internasional yang berimplikasi pada lambatnya pembangunan dan pemakmuran bangsa-bangsa. ${ }^{2}$ Pasca perang dunia ke-II proteksi dan perdagangan curang kembali dilakukan oleh

${ }^{1}$ David Held and Anthony McGrew, Globalization Theory: Aproach and Controversies (Cambridge: Polity, 2007).

2 Mark Skousen, Teori-Teori Ekonomi Modern (Jakarta: Pernada, 2001). 
negara-negara sebagai bentuk mempertahankan ekonominya dan berdampak pada faktor produksi yang mengakibatkan konsumen kesulitan mendapat barang berkulaitas baik dengan harga yang kompetitif. ${ }^{3}$ Salah satunya yaitu dumping. Pengertian dari dumping dalam perspektif hukum perdagangan internasional adalah suatu bentuk persaingan usaha tidak sehat antar harga internasional yang dilakukan oleh badan usaha, pelaku usaha atau negara pengekspor, yang menjual barangnya dengan harga lebih rendah di pasar luar negeri dibandingkan di pasar dalam negeri sendiri, bertujuan untuk mendapatkan keuntungan atas produk ekspor sebanyakbanyaknya. ${ }^{4}$ Dumping berdasarkan pasal VI Perjanjian Umum Tarif dan Perdagangan (GATT) adalah praktik suatu negara yang menjual produknya di negara lain dengan harga di bawah harga normal dengan maksud merebut pasar. Batasan pengertian harga di bawah harga normal, yaitu: a. lebih rendah dari harga produk di negara produk tersebut akan dikonsumsi di negara pengekspor (harga domestik); b. ketika tidak ada petunjuk mengenai harga domestik, harga normal adalah harga tertinggi untuk produk tersebut yang ditunjuk atau diekspor ke negara ketiga; atau c. biaya produksi untuk produk tersebut ditambah biaya tambahan (ongkos-ongkos) dan keuntungan yang layak.

Keinginan dalam bersaing di dunia perdagangan internasional, dilandasi dengan tujuan dasar utama untuk mendapatkan keuntungan sebanyak banyaknya. Pelaku usaha secara jelas mempunyai keinginan untuk mendapatkan pendapatan banyak tidak jarang pelaku usaha melakukan kegiatan usaha dengan cara melakukan kecurangan, salah satunya dengan mengekspor suatu produk dan menetapkan harga lebih rendah terhadap produk yang sama pada negara yang akan diimpor. ${ }^{5}$ Hal tersebut mengakibatkan unfair trade practice atau persaingan usaha tidak sehat yaitu persaingan antar pelaku usaha dalam menjalankan kegiatan produksi dan atau pemasaran barang atau jasa yang dilakukan dengan cara tidak jujur atau melawan hukum atau menghambat persaingan usaha.

Amerika Serikat mengepalai pencetusan perdagangan multilateral dengan rekan dagangnya terutama Inggris, sehingga melahirkan dua kerangka berpikir, yaitu Repriocal Trade Agreement Act 1934 dan General Agreement on Tariff and Trade (GATT) 1947. ${ }^{6}$ Pengaturan mengenai dumping baru dituangkan setahun setelahnya pada Article VI karena banyaknya kebijakan negara yang menyebabkan kerugian dan perlakuan tidak adil sehingga berdampak pada kebangkrutan Industri Dalam Negeri. ${ }^{7}$ Penyempurnaan peraturan tenatang dumping terus disempurnakan

\footnotetext{
3 John H Jackson, International Economic Law (EBerhart, 1997).

${ }^{4}$ Febrina R, "Dampak Kegiatan Jual Rugi (Predatory Pricing) Yang Dilakukan Pelaku Usaha Dalam Perspektif Persaingan Usaha," Jurnal Selat 4, no. 2 (2017): 234-49.

5 L Budi Kagramanto, Mengenal Hukum Persaingan Usaha (Sidoarjo: Laras, 2015).

6 Jackson, International Economic Law.

7 Yulianto Syahyu, Hukum Antidumping Di Indonesia (Jakarta: Ghalia, 2014).
} 
pertemuan demi pertemuan sehingga terciptanya Antidumping Code 1994 menggantikan Antidumping Agreement 1979 yang secara sah ditanda tangani bersamaan dengan Agreement Estabilishing the World Trade Organization (WTO). ${ }^{8}$

Dumping adalah masalah yang sering disoroti, karena salah satu praktik curang yang sering terjadi dalam konteks perdagangan internasional yang dapat menimbulkan kerugian suatu kegiatan perekonomian negara, dimana dumping itu dilakukan. Dalam kamus hukum Black Law's “dumping is the act of selling a large quantity of goods at less than fair value; also, selling goods abroad at less than the mareket price at home." Menurut Folsom "dumping as selling goods abroad at lower prices than the same items at home or not at its normal price". Menurut Huala Adolf, dalam bukunya yang berjudul Prinsip Hukum Perdagangan Internasional menjelaskan bahwa "dumping adalah penjualan suatu produk diluar negeri dengan harga yang lebih rendah daripada harga didalam negeri atau harga di pasar di negara yang mengimpor barang tersebut." Bahwa dari beberapa pengertian dumping diatas dapat disimpulkan bahwa dumping adalah sebuah praktik diskriminasi harga yang lebih rendah harga jualnya oleh eksportir yang dilakukan di luar negaranya atau negara ketiga dengan tujuan mendapat keuntungan, sehingga berdampak pada ketidak adilan harga bagi industri negara pengimpor. Kebijaksanaan antidumping merupakan suatu ketentuan-ketentuan yang menyoroti praktik dumping dan penjatuhan sanksi dalam perdagangan internasional.

Dalam artikelnya Apryani (2014) dengan judul "Dumping Dan AntiDumping Sebagai Bentuk Unfair Trade Practic", menerangkan dalam perdagangan internasional hanya bertujuan untuk mengetahui pengaturan dumping dan antidumping dan juga menganalisa kedudukannya dalam Pasal VI GATT. ${ }^{9}$ Penelitian oleh Kamilah (2015) dengan judul "Law Protection For Domestic Industries Due To Dumping Practice”, membahas tentang faktor-faktor apa yang menyebabkan suatu korporasi melaksanakan praktik dumping, serta bagaimanakah perlindungan hukum terhadap suatu negara akibat praktik dumping. ${ }^{10}$ Perbedaan dengan penelitian sebelumnya adalah artikel ini membahas mengenai anti dumping dalam produk Baja Lapis Aluminium Seng (BjLAS) yang belum pernah di bahas oleh jurnal-jurnal terdahulu. Tujuan dari penulisan artikel ini adalah untuk menganalisis upaya hukum yang tepat dan yang dapat dilakukan Indonesia terhadap tindakan dumping yang dilakukan Republik Rakyat Tiongkok

\footnotetext{
8 Syahyu.

9 Ni Wayan Ella Apryani and Ayu Putu Laksmi Danyathi, "Dumping Dan Anti-Dumping Sebagai Bentuk Unfair Trade Practice Dalam Perdagangan Internasional," Kertha Negara 02, no. 03 (2014).

10 Anita Kamilah, "Law Protection For Domestic Industries Due To Dumping Practice," Dinamika Hukum 15, no. 03 (2015), https://doi.org/http://dx.doi.org/10.20884/1.jdh.2015.15.3.407.
} 
dan Vietnam agar industri besi dan baja di Indonesia dapat bertahan dan berkembang baik di dalam maupun di luar negeri.

\section{B. Permasalahan}

Indonesia pada tahun 2017 tercatat mengkonsumsi baja sebanyak 13,59 juta ton pertahun dengan nilai produksi sebesar $48 \%$ atau sekitar 6,5 juta ton per tahun dan impor sebesar 52\%atau sekitar 7 juta ton pertahun. ${ }^{11}$ Tercatat komoditas besi dan baja sebagai komoditas impor terbesar ke-III sebesar 6,45\% dari total importasi atau sekitar US\$ 10,25 Miliar. ${ }^{12}$ Akan tetapi produk impor berupa Baja Lapis Aluminium Seng (BjLAS) yang berasal dari Republik Rakyat Tiongkok dan Vietnam menjadi sorotan karena megalami peningkatan dengan angka yang cukup signifikan selama 3 tahun terakhir, yaitu sebesar 27\% tercatat sejak tahun 2016 sebesar 463.375 ton per tahun menjadi 748.400 ton per tahun pada tahun 2018, selain itu kedua produk dari kedua negara tersebut memiliki nilai dominan sebesar 90\% dari total BjLAS di Indonesia. ${ }^{13}$ Berdasarkan pada Pasal 5 Peraturan Pemerintah Nomor 34 Tahun 2011 tentang Tindakan Antidumping, Tindakan Imbalan, dan Tindakan Pengamanan Perdagangan, Peraturan Mentri Perdagangan Republik Indonesia nomor 76/M-DAG/PER/12/2012 tentang Cara Penyidikan dalam Rangka Pengendalian Tindakan Antidumping dan Tindakan Imbalan dan Tindakan Pengamanan Perdagangan, Peraturan Mentri Perdagangan Republik Indonesia nomor 53/M-DAG/PER/9/2013, Komite Anti Dumping Indonesia memulai melakukan penyelidikan. Berdasarkan permasalahan tersebut maka penulisan artikel ini membahas upaya hukum yang dilakukan Indonesia terhadap dumping yang dilakukan Republik Rakyat Tiongkok dan Vietnam dalam perdagangan produk BjLAS di Indonesia.

\section{Metode Penelitian}

Penelitian lahir bermula dari rasa ingin tahu (niewgierigheid) untuk menemukan jawaban terhadap suatu permasalahan aktual yang dihadapi. Suatu penelitian ilmiah dilakukan untuk mencari kebenaran objek yang diteliti dengan tata cara yang diakui oleh ilmuan sejawat dalam bidang keahlian (intersubjektif), sehingga dengan begitu hasil penelitiannya diakui sifat keilmiahannya (etenschappelijkheid), agar dapat ditelusuri kembali kebenarannya oleh sejawat yang berminat dan merupakan hal yang baru (nieuw moet zijn). ${ }^{14}$ Dalam penelitian

11 Tan Ah Young, "Performance of the ASEAN Iron and Steel Industry in 2017," South East Asia Iron and Steel Institute (SEAISI), 2017.

12 "Ekspor Besi Dan Baja Menurut Tujuan Negara Utama Periode 2012-2017," in Badan Pusat Statistik, n.d., http://www.bps.go.id/staticable/2019/02/27/2033/ekspor-besi-baja-menurut-tujuan-negarautama-2012-2017.html.

13 Yustinus Andri DP, "Dugaan Dumping: RI Selidiki Baja Lapis Almunium Seng Asal Cina \& Vietnam," in Bisnis.Com, 2019, https://ekonomi.bisnis.com/read/20190828/12/1141997/dugaan-dumping-riselidiki-baja-lapis-aluminium-seng-asal-china-vietnam.

14 Jonaedi Efendi, Metode Penelitian Hukum Dan Empiris (Jakarta: Kencana, 2016). 
hukum adalah suatu kegiatan how-know bukan hanya sekedar know-about, karena yang dicari adalah pemecahan atas suatu isu hukum yang ada. Menurut Cohen, dibutuhkan kemampuan untuk mengidentifikasi masalah hukum, melakukan penalaran hukum, menganalisis masalah yang dihadapi dan memecahkan masalah tersebut. ${ }^{15}$ Pendekatan yang digunakan adalah pendekatan undang-undang (statue approach) adalah pendekatan yang penting dalam penelitian hukum normatif, karena berfungsi sebagai dasar petunjuk atau roadmap bagi langkah hukum yang ingin dilakukan untuk menjawab rumusan masalah dalam karya tulis ilmiah ini, sehingga kesesuaian dan konsistensi antara perjanjian internasional, undangundang dan atau regulasi dapat dipelajari. Kemudian pendekatan secara konseptual (conceptual approach) adalah pandangan yang berangkat dari pandangan dan doktrin-doktrin yang berkembang dalam ilmu hukum terkair perkembangan dumping dan organisasi dagang dunia. Maka dengan demikian penulisan ini memilih pendekatan secara undang-undang dan konseptual dalam penelitian ini.

Bahan hukum yang digunakan adalah bahan hukum primer, yaitu bahan yang bersifat autoritatif, yang artinya memiliki otoritas seperti: perundang-undanangan, catatan resmi atau risalah. Dalam proses pembuatan undang-undang dan putusanputusan hakim. Bahan hukum sekunder adalah semua publikasi tentang hukum yang bukan merupakan dokumen-dokumen resmi, melaikan berupa publikasi hukum yang meliputi: buku-buku hukum, kamus hukum, jurnal-jurnal hukum atau putusan pengadilan. ${ }^{16}$ Dan Bahan non-hukum berfungsi sebagai perluasan dari penulisan dalam mengidentifikasi dan menganalisis fakta secara akurat dan pemahaman atas isu hukum yang dihadapi. ${ }^{17}$ Menurut Peter Mahmud Marzuki, dalam melakukan suatu penelitian hukum kita dapat melakukan langkah-langkan sebagai berikut: ${ }^{18}$ 1) Mengidentifikasi fakta hukum dan mengeliminasi hal-hal yang tidak relevan untuk memecahkan isu hukum yang hendak didapatkan; 2) Pengumpulan bahan-bahan hukum dan bahan non-hukum yang juga memiliki relevansi; 3) Melakukan telaah atas isu hukum, berdasarkan bahan yang dikumpulkan; 4) Menarik kesimpulan dalam bentuk argumentasi yang menjawab isu hukum; dan 5) Memberikan preskripsi berdasarkan argumentasi yang telah dibangun dalam kesimpulan.

\section{HASIL DAN PEMBAHASAN}

Dumping berasal dari bahasa inggris yang secara bahasa berasal dari kata dump; is "to put down or drop someting in a careless way" yang artinya menjatuhkan sesuatu dengan cara yang berbeda, atau dumping: is "the practice of selling goods in another country so cheaply that companies in that country cannot 2016).

15 Peter Mahmud Marzuki, Penelitian Hukum (Edisi Revisi) (Jakarta: Kencana Prenadamedia Group,

\footnotetext{
16 Marzuki.

17 Marzuki.

18 Marzuki.
} 
compete fairly" yang artinya praktik menjual barang di negara lain dengan sangat murah sehingga perusahaan dinegara itu tidak dapat bersaing secara adil. ${ }^{19}$ Dumping dalam Black Law's “dumping is the act of selling a large quantity of goods at less than fair value; also, selling goods abroad at less than the mareket price at home". ${ }^{20}$ Dumping dalam kamus ekonomi adalah penjualan barang secara besar-besaran didaerah pemasaran lain, biasanya diluar negeri yang lebih rendah dari dalam negeri. ${ }^{21}$ Beberapa ahli hukum juga memberikan pengertian mengenai dumping, menurut Folsom "dumping as selling goods abroad at lower prices than the same items at home or not at its normal price". ${ }^{22}$ Menurut Huala Adolf dalam bukunya yang berjudul "Prinsip Hukum Perdagangan Internasional" menjelaskan bahwa dumping adalah penjualan suatu produk diluar negeri dengan harga yang lebih rendah daripada harga didalam negeri atau harga di pasar di negara yang mengimpor barang tersebut. ${ }^{23}$ Berdasarkan beberapa pengertian dumping diatas dapat disimpulkan bahwa dumping adalah sebuah praktik diskriminasi harga yang lebih rendah harga jualnya oleh eksportir yang dilakukan di luar negaranya atau negara ketiga dengan tujuan mendapat keuntungan, sehingga berdampak pada ketidak adilan harga bagi industri negara pengimpor.

\section{A. Tindakan Antidumping Pada Baja Lapis Almunium Seng (BjLAS)}

Offensive (i.e the improved market accesss that they aim to achiev in the market of their trading partners) ${ }^{24}$ Offensive trade instrument aim to improve market acces for EU operators in third countries (i.e the Trade Barriers Regulation [No. 3286/94], enable EU businesses to request that the Erupean Commission investigate and challenge market access barriers in forgein markets [including those applicable to goods, services and intellectual property rights], using WTO or other mechanism if necessary. ${ }^{25}$

Dari penjelasan tersebut dapat diartikan bahwa tindakan antidumping secara offense ada sebagai bentuk pengamanan pada akses pasar asing atau dapat melakukan permohonan pada lembaga otoritas pasar negara ketiga, salah satunya dengan cara melakukan investigasi tentang adanya perlindungan non-tarif dan hambatan yang terjadi pada pasar asing (foreign) yang merugikan industri dalam negeri. Defensive Interest (i.e the protective barriers in their own markets that the

19 "Cambridge International Dictionary of English," in Cambridge Unviersity Press, Cambridge, 1995.

${ }^{20}$ Henry Campbell Black, "Black's Law Dictionary," in West Publisihing Co, 1979.

21 Sri Redjeki Hartono, Kapita Selekta Hukum Ekonomi (Bandung: Bandar Maju, 2000).

22 Ralph Folsom, International Bussiness Transaction (St. Paul: minn, 2000).

${ }^{23}$ Huala Adolf, Prinsip Hukum Perdagangan Internasional (Bandung: Refika Aditama, 2018).

24 Carig Van Grasstek, History and the Future of World Trade Organization (World Trade Organization, 2013).

25 Arnoud R Willems, Sven De Knop, and Jeremle Charles, The Handbook of Trade Enforcement 2012 (European Commision) (Global Competition Review, 2012). 
affected industries demand be preserved). ${ }^{26}$ Defensive trade instrument aim to protect the EU market against the import of product causing injury into EU producers of the same similar or product. The most prominent defensive trade mechanism are the anti-dumping, anti-subsidy, and safe guard instrument. ${ }^{27}$

Tindakan antidumping dalam bentuk perlindungan perdagangan (Defensive) dilakukan apabila industri dalam negeri dipasar domestik mengalami kerugian terhadap barang sejenis yang diekspor oleh negara lain dengan harga dibawah normal (unfair) sehingga berdampak buruk (causal link) bagi industri dalam negeri yang sudah berdiri dalam menggembangkan usahanya dan yang akan mendirikan industri, dengan alasan tersebut maka perlindungan (protect) pasar domestik terhadap produk impor yang menyebabkan kerugian terhadap produk barang sejenis dengan cara melakukan tindakan antidumping, antisubsidi. ${ }^{28}$

Pengkategorian barang sejenis Baja Lapis Almunium Seng (BjLAS) apabila mengacu pada pengertian Dirjen Bina Konstruksi adalah baja lembaran dan gulungan hasil canai dingin yang dilapisi dengan cara dicelup panas dengan paduan almunium 50\% - 60\%, seng 40\% - 50\% dan sisanya adalah unsur lain. Biasanya dalam dunia bisnis baja disebut dengan galvanis (GL). Spesifikasi teknis dan cara uji baja lapis jenis ini telah distandarkan dengan SNI Wajib SNI 4096:2007 yang biasanya diaplikasikan dalam bentuk penutup atap; penutup dinding; rangka atap; rangka dinding. ${ }^{29}$

Keberadaan antidumping bertugas sebagai perlawanan harga impor yang dilakukan dengan harga tidak adil (unfair) kepasar lain. Merujuk pada Antidumping Code 1994, sebelum terlahir kebijakan tentang tindakan antidumping setidaknya ada 3 (tiga) hal yang harus ditemukan: pertama, harus menemukan bukti barang yang diduga melakukan dumping oleh produsen asing; kedua, adanya industri dalam negeri barang sejenis yang mengalami ancaman atau kerugian; dan ketiga, ditemukan benar bahwa dumping adalah penyebab kerugiannya. ${ }^{30}$ Berikut penjelasan perbagian dalam pasal demi pasal:

1. Barang sejenis (like product) adalah semua aspek seperti karakter fisik, teknik, susunan kimiawi, maupun penggunaannya. adapun pengujian barang sejenis dapat diketahui dari karakter fisik, unsur kimia, teknologi mesin, proses produksi, tingkat kualitas, fungsi atau aplikasi, kecenderungan konsumen, segmen pasar, biaya, harga, dan kelompok, hal

${ }^{26}$ Grasstek, History and the Future of World Trade Organization.

27 Willems, Knop, and Charles, The Handbook of Trade Enforcement 2012 (European Commision).

28 Alhayat A P, "Efektivitas Tindakan Anti Dumping Indonesia 1996-2010," Buletin Ilmiah Perdagangan 8, no. 2 (2014): 247-68.

29 "Katalog Produk Baja Ringan Konstruksi 2018," in Direktorat Bina Kelembagaan Dan Sumber Jasa Konstruksi, Direktorat Jendral Bina Konstruksi, Kementrian Pekerjaan Umum Dan Perumahan Rakyat. Katalog Produk Baja Ringan Konstruksi 2018 (Edisi Pertama: Cetakan Pertama). Oktober 2018, 2018. (2012): 9 .

${ }_{30}$ Mark Wu, “Antidumping in Asia's Emerging Giants," Harvard International Law Journal 53, no. 1 
tersebut menjadi dasar bahwa apakah benar barang yang diduga dumping merupakan barang yang sejenis.

2. Penjualan barang lebih rendah dari harga normal (less than normal value) barang dumping adalah sebuah tindakan penjualan yang dilakukan oleh produk suatu negara yang lebih rendah dari harga normalnya.

3. Kerugian (injury) yang dimaksud adalah dampak dari penjualan dibawah harga normal menjadikan kerugian material, ancaman kerugian, atau penghambat bagi industri dalam negeri serupa yang mau berdiri dan merugikan bagi industri yang sedang beroprasi untuk mengindentifikasi suatu perbuatan dumping itu menimbulkan kerugian materiil atau tidak kerugian yang menjadi bukti haruslah berdasarkan pada bukti pengajuan atas kausualitas tersbut, yaitu pada: efek volume impor barang dumping terhadap barang sejenis dipasar dalam negeri, kemudian efek harga barang dumping terhdap barang sejenis didalam negeri dan kerugian yang diderita industri dalam negeri akibat barang dumping tersebut. Sedangkan pengujian kerugian industri dalam negeri dapat dilihat melalui indikator sebagai berikut: penurunan penjualan dalam negeri, penurunan keuntungan, penurunan produksi, penurunan persebaran pasar, penurunan produktivitas, tingkat pengembalian investasi; utilisasi kapasitas produksi; harga dalam negeri, dan sebagainya.

4. Industri dalam negeri (domestic industry) adalah produsen dalam negeri yang memproduksi barang sejenis atau kelompok produsen yang secara kolektif memproduksi sebagian besar dari produksi dalam negeri. Adapun sengketa antidumping dimulai ketika produsen atau industri dalam negeri secara sendiri atau dibawah asosiasi dianggap cukup (memenuhi standar minimal) untuk dilakukannya sebuah penyelidikan dibawah lembaga pemerintah.

5. Adanya hubungan kausalitas (causal link) antara barang yang dijual oleh pengimpor dengan harga dibawah normal dan kerugian yang dialami negara antara negara. Hal itu harus didasarkan pada pengujian yang mencakup semua faktor ekonomi dalam mengidentifikasi kerugian yang dialami industri dalam negeri seperti yang tertera sebelumnya.

Dari beberapa tolak ukur yang ada, Yulianto Syahyu membagikan implikasi dari praktik dumping bagi negara importir kedalam 3 (tiga) bagian. Pertama, tingkat produksi (level of output) dibawah tekanan diskriminasi harga mungkin memiliki nilai yang lebih besar dengan keadaan dibawah pengaruh harga monopoli tunggal, yang pada kenyataannya jika pembeli bersedia membayar sesuai dengan kurva permintaan klasik, yaitu apabila pada saat permintaan meningkat maka harga akan meningkat dan begitupun sebaliknya, maka total output akan cenderung sama dengan output pada situasi industri yang kompetitif. Adapun kemungkinan lain bagi 
kaum monopolistik untuk melakukan diskriminasi harga untuk mengurangi output disalah satu pasar, oleh karena itu maka tidak ada teori umum dan pasti yang menjelaskan tentang dampak daridiskriminasi harga terhadap tingkat produksi. Dapat disimpulkan bahwa diskriminasi harga dalam perdagangan internasional dalam setiap situasi harus dianalisis secara khusus dan dumping tidak berbeda denga harga rendah lainnya. Kedua, penyebaran pendapatan (income distribution) bagi para produsen barang sejenis akan mengalami kehilangan keuntungan karena dilakukannya praktik dumping yang berdampak pada para pemegang saham yang kehilangan devidennya sehingga beberapa pekerja akan kehilangan pekerjaannya untuk beberapa waktu kedepan dan barang-barang dumping akan secara langsung menjadi keuntungan bagi para konsumen. Ketiga, dampak terhadap proses kompetisi dalam perdagangan internasional (effects on the competitive process in international trade) damapak diskriminasi harga terhadap kompetisi sangatlah bervariasi, yang dapat terjadi baik secara vertikal ataupun secara horizontal. ${ }^{31}$ Adapun implikasi tersebut antara lain:

a. Apabila diskriminasi harga adalah sebuah perpindahan dari monopoli berubah kepada kebiasaan yang lebih kompetitif, maka diskriminasi harga berpihak kepada persaingan.

b. Apabila diskriminasi harga membantu perusakan kartel internasional, maka akan menjadi prokompetitif terhadap negara importir dan negara eksportir.

c. Apabila diskriminasi harga menjadi bukti adanya perlindungan perdagangan akan rusaknya sistem ekonomi, maka hal tersebut akan menjadi antikompetitif.

Diskriminasi harga horizontal adalah diskriminasi yang dilakukan terhadap pesaing pada tingkat industri yang sama yang nantinya akan berdampak pada menghilangkan beberapa pesaing dinegara pengimpor. Namun, tindakan dumping ini menguntungkan bagi industri hilir di negara pengimpor apabila barang yang dijual berbentuk bahan baku yang akan menguntungkan bagi industri hilir dalam negeri yang menggunakannya. J. Soedrajad Dwiwandono mempunyai pendapat hukum bahwa di Indonesia sendiri banyak terdapat kelemahan di bidang ekonomi, yang menyangkut persaingan usaha dalam hal ini seperti penawaran maupun permintaan. Hukum penawaran mempunyai keterkaitan antar jumlah barang yang akan ditawarkan dengan tingkat harga. Harga suatu produk berbanding lurus dengan jumlah penawaran. Apabila harga semakin tinggi, maka para produsen akan berkompetisi menjual barangnya sehingga penawaran suatu barang pun meningkat.

31 Thomas J Prausa, “Anti-Dumping: A Growing Problem in International Trade, Vol. 28, No. 5, 2005, Hlm. 683.,” The World Economy 28, no. 5 (2005): 683. 
Sementara itu, apabila harga barang mulai turun, maka para produsen akan menyimpan semua produknya di dalam gudang sehingga jumlah penawaran akan semakin berkurang. ${ }^{32}$ Konsep dasar dari dumping sendiri sebenarnya adalah predatory pricing, yaitu produsen menjual rugi suatu barang atau jasa dalam periode waktu tertentu dengan bermaksud mematikan pesaingnya. Dumping mulai diberlakukan di Republik Indonesia akibat hukum diratifikasinya Agreement on Establishment of World Trade Organization (WTO) Melalui Undang-Undang No 7/1994. Sampai saat ini, Indonesia belum mempunyai undang undang yang secara khusus mengatur mengenai dumping itu sendiri. Praktek dumping pun hanya disinggung dalam beberapa pasal di Undang-Undang No. 17 tahun 2006 Tentang kepabean. ${ }^{33}$

Diskriminasi harga dalam ruang lingkup perdagangan internasional biasanya memiliki peraturan yang kaku dan cenderung memberikan harga yang tinggi bagi konsumen dalam negeri. Namun dengan memperluas kesempatan pasar ekspor barang dunping juga dapat menguntungkan konsumen dalam negeri karena memungkinkan adanya biaya produksi yang rendah, investasi yang lebih besar untuk produk-produk baru dan peningkatan produksi yang dapat menambah kesejahteraan dari kosumen barang dumping. Konsekuensi dari praktik dumping yang dilakukan oleh eksportir, maka akan terjadi pembatasan penjualan didalam negeri sehingga berdampak pada investasi untuk penelitian dan pengembangan serta peningkatan suber daya manusia. Selain itu akan terjadi kecenderungan tertutupnya pasar negara pengekspor terhadap produk sejenis dari negara lain terutapa ketika terjadi subsidi silang atas barang dumping tersebut. Dan menurut ahli ekonomi menjelaskan bahwa tidak dapat dibenarkan penjualan dibawah harga harga dan diskriminasi harga apabila ada pemangsaan atau subsidi silang apapun alasannya. Karena secara tidak langsung dan dalam jangka waktu yang panjang akan berdampak kerugian pula bagi negara eksportir. Praktek dumping dapat dapat dilakukan dengan cara membandingkan antara harga normal (normal value) dengan harga ekspor. Harga normal biasanya didasari pada penjualan di pasar domestik negara pengekspor. Bila harga ekspor ternyata lebih rendah dari harga normal, artinya memang telah terjadi dumping. ${ }^{34}$

\footnotetext{
32 Sadi Muhammad, Hukum Persaingan Usaha Di Indonesia (Sebagai Upaya Penguatan Lembaga Komisi Pengawas Persaingan Usaha KPPU) (Malang: Setara Press, 2016).

33 Anggraini Nita, "Dumping Dalam Perspektif Hukum Dagang Internasional Dan Hukum Islam," Mazahib Jurnal Pemikiran Hukum Islam 14, no. 2 (2015).

${ }^{34}$ Kagramanto, Mengenal Hukum Persaingan Usaha.
} 


\section{B. Kepastian Dalam Penyelesaian Hukum Oleh Indonesia Pada Dumping Yang Dilakukan Republik Rakyat Tiongkok Dan Vietnam}

Hukum tanpa nilai kepastian akan kehilangan makna karena tidak dapat lagi digunakan sebagai pedoman perilaku bagi setiap orang. Kepastian sendiri disebut sebagai salah satu tujuan dari hukum selain keadilan dan kemanfaatan. Radbruch memberi pendapat yang mendasar mengenai kepastian hukum. Ada 4 hal yang berhubungan dengan makna kepastian hukum :

a. Hukum itu positif, yaitu peraturan perundang-undangan

b. Hukum itu didasarkan pada fakta atau hukum yang ditetapkan itu pasti

c. Kenyataan (fakta) harus dirumuskan dengan cara yang jelas sehingga menghindari kekeliruan dalam pemaknaan, disamping mudah dilaksanakan

d. Hukum positif tidak boleh mudah di ubah.

Kepastian hukum bersumber dari pemikiran positifis dari dunia hukum yang dianut oleh aliran Yuridis Dogmatis, yang dipandang dari sudut ilmu hukum positif/normatif atau yuridis dogmatik, tujuan hukum dititik beratkan pada segi kepastian hukumnya, yang cenderung melihat hukum sebagai sesuatu yang otonom, yang mandiri, karena bagi penganut pemikiran ini hukum tak lain hanya kumpulan aturan. Bagi aliran ini tujuan hukum tidak lain dari sekedar menjamin terwujudnya kepastian hukum. Ahmad Ali menjelaskan:

Maksud pada penganut aliran ini "janji hukum" yang tertuang dalam rumusan aturan tadi, merupakan "kepastian" yang harus diwujudkan. Aliran ini melupakan bahwa sebenarnya "janji hukum" itu bukan suatu yang "harus" tetapi suatu yang "seharusnya". Dapat mengerti bahwa apa yang seharusnya (sollen) belum tentu terwujud dalam kenyataan (sein).

Dalam artikel ini, pihak yang berkepentingan dalam tindakan antidumping adalah eksportir, eksportir produsen, pemerintah negara pengekspor, pemohon atau industri dalam negeri, importir, yang terlibat dalam penyelidikan tindakan antidumping. Komite Anti Dumping Indonesia (KADI) adalah badan teknis yang menanggulangi importasi barang dumping atau mengandung subsidi yang berakibatkan kerugian pada industri barang sejenis dalam negeri memiliki beberapa fungsi, tugas dan kedudukan yang bertanggung jawab kepada Menteri Perdagangan Republik Indonesia dengan dibebani tugas secara khusus menangani permasalahanpermasalahan yang berkaitan dengan upaya penanggulangan importasi barang dumping dan barang mengandung subsidi yang seluruh pembiayaannya dimasukan kedalam Anggaran Pendapatan dan Belanja Negara (APBN) dibawah Kementerian Perdagangan sebagaiman diatur dalam Peraturan Menteri Perdagangan Republik Indonesia Nomor 33/M-DAG/PER/2014 tentang Organisasi dan Tata Kerja Komite Anti Dumping Indonesia. Pasal 1 angka 8 menjelaskan yang dimaksud dengan 
Industri Dalam Negeri (IDN) adalah produsen dalam negeri secara keseluruhan dari barang sejenis atau secara kumulatif produksinya (asosiasi) merupakan proporsi yang besar dari keseluruhan produksi barang sejenis. Pasal 4 dan Pasal 5 menerangkan bahwa IDN dianggap mewakili apabila produsen atau asosiasi dalam negeri barang sejenis apabila produksinya lebih dari 50\% (lima puluh persen). Penyelidikan hanya dapat dilakukan apabila produksi pemohon atau produksi dari pemohon atau yang turut mendukung berjumlah 25\% (dua puluh lima persen) dari produksi dalam negeri barang sejenis. Dan penyelidikan tidak dapat dilakukan apabila nilai marjin dumping berada dibawah $2 \%$ (dua persen) dari harga ekspor dan/atau volume impor barang dumping kurang dari 3\% (tiga persen) atau 7\% (tujuh persen) pada volume barang dumping yang dilakukan beberapa negara secara kumulatif atau total impor barang sejenis. Apabila persyaratan yang diajukan belum lengkap maka pemohon akan diberi kesempatan untuk melengkapi permohonan data dan informasi.

Persyaratan permohonan tindakan antidumping terbagi menjadi dua, yaitu persyaratan formil dan persyaratan metriil, dijelaskan sebagai berikut:

1. Persyaratan Formil

Proses pengajuan peromohonan penyelidikan sebagaimana yang dijelaskan dalam pasal 3 wajib diajukan secara tertulis berbahasa indonesia kepada Ketua KADI dengan informasi menyebutkan identitas pemohon memuat sekurang-kurangnya nama perusahaan, alamat kantor, alamat pabrik, nomor telepon kantor, nomor telepon pabrik, nomor faksimile, dan nama dan nomor telepon orang tertentu yang dapat dihubungi (contact person). Selain itu informasi lainnya terkait nama dan alamat eksportir dan/atau eksportir produsen dan importir yang diketahui secara lengkap dan benar serta uraian lengkap barang impor yang dituduh dumping dan/atau mengandung subsidi dan nomor pos tarif (sepuluh digit sesuai dengan ketentuan peraturan perundang-undangan dibidang kepabeanan)

2. Persyaratan Materiil

Permohonan persyaratan tersebut harus dilakukan secara tertulis dan wajib berbahasa indonesia dan menyampaikan data dan/atau informasi secara tertulis mengenai: Pertama, keterangan umum (latar belakang permohonan penyelidikan, data permohonan yang berisikan; nama, alamat lengkap dan nomor telepon; kantor perusahaan dan pabrik, akta pendirian perusahaan, ijin usaha industri) informasi tentang industri dalam negeri, deskripsi dan proses barang yang diduga dumping atau subsidi, negara pengekspor dan produsen/eksportir, importir yang diketahui. Kedua, dugaan dumping dan atau, perhitungan normal, dan harga ekspor yang memuat: total produksi barang sejenis yang dihasilkan oleh pemohon dan produsen dalam negeri lainnya; volume dan nilai impor barang yang 
dituduh dumping dan/atau subsidi sekurang-kurangnya tiga tahun terakhir; tuduhan dumping dan/atau subsidi yang mencakup (nilai normal, harga ekspor, besaran margin dumping); kerugian; dan hubungan sebab akibat antara barang dumping dengan kerugian; Ketiga, analisis mengenai kerugian yang dialami pemohon berisikan: kerugian pemohon, data impor dari negara yang dituduh dumping dan atau subsidi, perkembangan indikator (produksi, kapasitas terpasang, utilisasi, persediaan, penjualan, ekspor) dalam negeri, price undercutting, price depression, dan price supperssion, kerugian material industri domestik akibat barang dumping (penurunan: penjualan dalam negeri, profit, produksi, utilisasi kapasitas, pangsa pasar, produktifitas); gangguan, return on invesment, cash flow, perubahan harga dalam negeri, persediaan meningkat, PHK, penurunan upah kerja, penurunan pertumbuhan, dan hubungan klausualitas antata dumping dan atau subsidi, dengan kerugian serta faktor-faktor lain penyebab kerugian. Dan Keempat, memenuhi syarat sebagaimana IDN yang ditentukan dalam pertaruan menteri perdaganga RI.

Penyelidikan antidumping melalui beberapa tahapan, sebagai berikut:

1. Pengujian Bukti Awal

Penyelidikan dapat dilakukan atas dasar permohonan industri dalam negeri dan Inisiatif KADI sendiri. Pengujian bukti awal dilakukan apabila proses penyelidian didasarkan atas permohonan dari industri dalam negeri barang sejenis, yang mana KADI melakukan pemerikasaan berkas yang dimohonkan selama 30 hari sejak berkas tersebut diterima. Proses pengujian antara lain adalah kelengkapan berkas sesuai dengan syarat dan ketentuan, kekuatan bukti akan terjadinya dumping, kesejenisan barang, hubungan yang bersangkutan antara dumping dengan kerugian yang diderita oleh industri dalam negeri. Apabila penyelidikan dilakukan atas inisiatif, maka pengujian dilakukan sebagai dasar KADI untuk melanjutkan kelangkah selanjutnya.

2. Pemberitahuan Awal

Sebelum dilakukannya penyelidikan KADI berkewajiban untuk memberikan pemberitahuan awal kepada perwakilan negara tertuduh kedutaan negara, yaitu Tiongkok dan Vietnam paling tidak 2 (dua) minggu sebelum penyelidikan dimulai.

3. Pengumuman atau Inisiasi

Pengumuman pemerintah tentang dimulainya penyelidikan akan diumumkan KADI melalui surat kabar yang berperedaran nasional dan siaran pers. Adapun pengumuman akan diberitahu kepada pihak yang berkepentingan, antara lain: 1) Eksportir, produsen luar negeri, atau importir barang yang diselidiki atau asosiasi yang mayoritas anggotanya 
adalah para eksportir, produsen atau importir BjLAS Tiongkok dan Vietnam; 2) Pemerintah negara pengekspor (Tiongkok dan Vietnam); 3) Produsen Barang sejenis didalam negeri, atau asosiasi produsen dalam negeri yang mayoritas anggotanya memproduksi barang sejenis;

4. Penyelidikan Pendahuluan

Proses penyelidikan yang dilakukan KADI terhadap dumping BjLAS yang dilakukan oleh Tiongkok dan Vietnam baru sampai pada tahap penyebaran kuisioner dan proses penyelidikan bersifat rahasia dan tertutup sehingga hasil dari penyelidikan yang dilakukan oleh KADI belum selesai dan belum dapat dipublikasikan. Namun apabila hasil dari penyelidikan dari KADI menemukan adanya indikasi dumping, maka KADI akan memberikan rekomendasi kepada menteri perdagangan untuk ditindak lanjuti dalam memperoleh pertimbangan dalam rangka kebijakan nasional dengan menteri terkait ataupun lembaga pemerintahan non kementrian sebagaiman diataur dalam pasal 10 jo pasal 25.

KADI akan melakukan penyelidikan untuk mendapatkan bukti-bukti tentang adanya dumping yang mengakibatkan kerugian bagi industri dalam negeri dengan cara:

a. Mengirimkan surat pemberitahuan kepada pihak terkait, yaitu: perwakilan pemerintah negara Tiongkok dan Vietnam di Jakarta, perwakilan pemerintah Indonesia di Tiongkok dan Vietnam, produsen atau eksportir di negara Tiongkok dan Vietnam, serta importir barang sejenis didalam negeri. Apabila terdapat pemohon dalam kasus yang berbeda maka pemohon juga di ikut sertakan.

b. Menerima kuisioner, meneliti, menerima bukti, melengkapi data, menerima penjelasan, menganalisis jawaban atas kuisioner, dan data lainnya dari produsen diluar negeri untuk mengetahui besarnya marjin dumping.

c. Melakukan verifikasi kepada pemohon dan importir dalam negeri, produsen atau eksportir luar negeri yang telah memberi informasi lengkap dengan jawaban kuisioner. Tujuan dari verifikasi adalah untuk memastikan kebenaran data-data yang disampaikan berdasarkan pada bukti-bukti yang akurat.

d. Menganalisis hasil verifikasi dan membuat kesimpulan tentang hasil penyelidikan dumping yang ditemukan atau tidak bukti dumping dan kerugian yag diakibatkan barang dumping.

e. Jika tidak ditemukan bukti maka KADI akan menghentikan proses penyelidikan dan mengumumkan penghentian tersebut, namun apabila ditemukan dumping maka akan dilakukan tindakan sementara. 


\section{Tindakan Sementara}

Tindakan Sementara yang dilakukan berupa Bea Masuk Anti Dumping Sementara (BMADS) oleh KADI dengan diberikannya laporan sementara hasil penyidikan kepada menteri apabila ditemukan bukti permulaan yang cukup mengenai adanya barang dumping yang menyebabkan kerugian dan diberitahukan kepada eksportir dan/atau eksportir produsen secara langsung melalui negara pengekspor, Pemohon atau IDN dan Importir, dengan catatan apabila marjin dumping telah ditemukan namun nilainya sangat kecil (deminimis) maka KADI akan memberhentikan tindakan penyelidikan, yang dimaksud dengan marjin dumping deminimis adalah kurang dari $2 \%$ (dua persen) dari harga ekspor. Selain itu KADI juga membuktikan apakah dumping tersebut berdampak pada IDN atau tidak sehingga mengalami kerugian.

6. Penyelidikan Lanjutan

Tindakan penyesuaian dapat dilakukan oleh KADI atau eksportir dan/atau eksportir produsen paling lambat tujuh hari setelah pengenaan BMADS atau laporan pendahuluan hasil penyelidikan dengan cara penyesuaian harga atau penghentian ekspor barang dumping. Namun hal itu dapat ditolak ataupun diterima apabila hasil dari tindakan penyesuaian tidak lagi berdampak kerugian. Tawaran tidakan penyesuian disampaikan paling lambat 7 (tujuh) hari sejak pengenaan BMADS atau laporan pendahuluan hasil penyelidikan apabila tidak ada pengenaan BMADS. Apabila KADI menyetujui tindakan penyesuaian maka akan dituangkan dalam nota kesepakatan dengan eksportir dan/atau eksportir produsen menyampaikan pelaksanaan tindakan sementara kepada KADI secara berkala dan bersedia untuk diverifikasi atas pelaksanaan tindakan penyesuaian selain itu penyelidikan akan dilakukan penundaan atau penghentian, namun apabila terjadi pelanggaran terhadap nota kesepakatan maka akan dikenakan tindakan sementara atau KADI melanjutkan penyelidikan. Dan apabila KADI melakukan penolakan terhadap tawaran tidakan penyesuaian akan disampaikan secara tertulis kepada eksportir dan/atau eksportir produsen.

7. Akhir Penyelidikan atau Pengenaan Bea Masuk Anti Dumping

KADI akan melakukan pemubktian dalam tahap akhir penyelidikan, apakah benar telah terjadi dumping yang merugikan bagi IDN. Melalui analisisnya KADI akan menghitung besaran marjin dumping anatara nilai normal dan nilai ekspor barang dumping yang harus dibandingkan dengan nilai ekspor pada tingkat perdagangan yang sama (same level of trade) yang akan menentukan besaran BMAD. Pengenaan BMAD dimulai sejak diberlakukannya Surat Keputusan Menteri Keuangan tentang pengenaan BMAD terhadap produk BjLAS Tiongkok dan Vietnam yang nantinya 
akan dijadikan dasar bagi Direktur Jendral Bea dan Cukai selaku bagian dari Menteri Keuangan yang melaksanakan pemungutan BMAD berdsarkan pada SE Direktur Jendral Bea dan Cukai No. SE-19/BC1997 tentang Petunjuk Pelaksanaan Bea Masuk Anti Dumping apabila terbukti melakukan dumping sesuai dengan ketentuan.

8. Peninjauan Kembali

Peninjauan Kembali dapat dilakukan atas permohonan atau inisiatif KADI sendiri. Permohonan paling cepat diajukan 12 (dua belas) bulan setelah berlakunya BMAD dengan menggunakan bahasa Indonesia secara tertulis, namun hal BMAD dapat ditinjau berdasarkan pada permohonan dari eksportir dan/atau eksportir produsen atau industri dalam negeri dan/atau importir yang kooperatif dalam proses penyelidikan, atau permohonan dari eksportir dan/atau eksportir produsen yang tidak melakukan ekspor barang dumping sebelum pengenaan $B M A D$. Peninjauan kembali terdiri atas Interim Review dan Sunset Review berikut penjelasannya. Berdasar Pasal 19 Interim Review diajukan oleh eksportir dan/atau eksportir produsen untuk melakukan penghentian, untuk tidak dikenakan dan untuk melakukan besaran BMAD. Namun dalam pasal 20 pengajuan juga dapat mendapatkan penolakan oleh KADI apabila terbukti dumping barangnya terbukti merugikan pasar Dalam Negeri. Hal ini dapat dilakukan dua belas bulan setelah penetapan BMAD. Sunset Review diajukan oleh pemohon atau industri dalam negeri untuk meminta perpanjangan pengeanaan BMAD baik disertai perubahan besaran ataupun tidak. Hal ini juga baru dapat dilakukan 12 (dua belas) bulan setelah penetapan BMAD.

Dalam praktiknya perdagangan internasional tidaklah berjalan dengan baik begitu saja, terkadang tuduhan dumping yang dianggap oleh negara lain benar ternyata tidak benar dan berdampak pada pengenaan BMAD. Maka tujuan pengenaan BMAD itu malah justru membuat rugi negara produsen dan melahirkan harga yang tidak fair bagi produsen dari negara pengekspor. Apabila hal tersebut terjadi, maka dapat dinaikkan ke forum WTO melalui negara pelaku Industri yang dikenakan BMAD, sesuai dengna ketentuan dalam GATT bahwa negara dapat melakukan sanggahan atas nama perodusen yang di vonis kepada The Committe on Antidumping Practices. ${ }^{35}$ Dibawah badan The Dispute Settelement Body (DSB).

Penerapan BMAD tidak selalu menyelesaikan permasalahan yang ada, melainkan minimalisir dari sebagian resiko yang terjadi, sehingga dampak yang timbul dari diterapkannya kebijakan anti dumping tentu akan lahir dengan sendirinya baik dari pihak negara yang industrinya dikenakan BMAD ataupun dari

35 "World Trade Organization Agreement about Understanding on Rules and Prosedur Governing the Settelement of Dispute (URP-GSD)," n.d. 
para pengguna barang dalam negeri. Sejatinya pengenaan BMAD dapat disikapi dengan bijak oleh para pihak yang terkena dampak dari diterbitkannya kebijakan berupa pengenaan BMAD. Bagi negara yang industrinya dikenakan BMAD yaitu pelaku produk BjLAS ini adalah Tiongkok dan Vietnam tentu akan mengubah harga menjadi lebih mahal sesuai dengan marjin dumping yang ditentukan sehingga menurunkan jumlah konsumen dari yang sebelumnya yang unggul akibat harga yang lebih murah walaupun kualitasnya tidak memenuhi Standar Nasional Indonesia (SNI). Bagi industri hilir yang memanfaatkan BjLAS Tiongkok dan Vietnam akan mengalami kerugian dari penerapan BMAD yang berdampak pada daya serap produk akibat keuntungan yang semakin mengecil karena harga yang berlaku lebih tinggi dari pada harga sebelumnya. Di luar perindustrian akan ada hubungan negara baik antar kedua negara yang dapat rusak akibat penerapan BMAD yang secara tidak langsung dianggap menggingkari perjanjian ACFTA yang telah disepakati khususnya oleh Indonesia selaku negara ASEAN dengan Tiongkok, tanpa terkecuali dengan Vietnam sehingga nantinya secara berkepanjangan akan berdampak pada kelancaran perdagangan, walaupun secara tidak langsung dumping-pun membuat perdagangan antar negara tidak lancar pula. Sedangkan dampak yang dirasakan pula oleh pengguna didalam negeri adalah kebijakan yang berada ditengah-tengah dua kepentingan antara industri hulu dan hilir yang sama-sama harus dilindungi kepentingannya, maka dari itu pertimbangan tindakan antidumping perlu dikaji secara matang, sehingga hasilnya tidak berdampak semakin buruk atau dapat meminimalisir permasalahan yang ada.

\section{PENUTUP}

Kepastian dalam penyelesaian hukum oleh Indonesia pada dumping yang dilakukan Republik Rakyat Tiongkok Dan Vietnam adalah dengan melakukan pengenaan Bea Masuk Anti Dumping (BMAD) oleh KADI berdasarkan pada angka marjin dumping yang dilakukan Tiongkok dan Vietnam, sehingga produk BjLAS Tiongkok dan Vietnam akan kembali pada harga normal atau wajar dan angin segar bagi Industri dan pasar produk BjLAS di Indonesia dapat dirasakan kembali bagi Industri yang sempat mengurangi bahkan terhenti produksinya. Saran bagi industri dalam negeri sebagai pelaku usaha yang mengalami dampak dari praktik dumping secara langsung harusnya lebih aktif dalam berinisiatif melakukan permohonan tindakan antidumping sebagai bentuk perlindungan terhadap industrinya. Kemudian, KADI yang mewakili pemerintah, dalam melakukan inisiatif atau langkah-langkah yang diperlukan harusnya lebih peka dalam menindak keluhan terkait tindakan antidumping produk BjLAS yang dilakukan oleh Tiongkok dan Vietnam. Adanya acara tahunan atau bentuk peringatan, capaian dan kepedulian bagi KADI dan para pelaku usaha dalam bidang tindakan antidumping. 


\section{DAFTAR PUSTAKA}

A Agreement on Implementation of Article VI General Agreement on Tariff and Trade 1994 (Anti-Dumping Code).

A P, Alhayat. "Efektivitas Tindakan Anti Dumping Indonesia 1996-2010." Buletin Ilmiah Perdagangan 8, no. 2 (2014): 247-68.

Adolf, Huala. Prinsip Hukum Perdagangan Internasional. Bandung: Refika Aditama, 2018.

Apryani, Ni Wayan Ella, and Ayu Putu Laksmi Danyathi. "Dumping Dan AntiDumping Sebagai Bentuk Unfair Trade Practice Dalam Perdagangan Internasional." Kertha Negara 02, no. 03 (2014).

Black, Henry Campbell. "Black’s Law Dictionary.” In West Publisihing Co, 1979. "Cambridge International Dictionary of English." In Cambridge Unviersity Press, Cambridge, 1995.

DP, Yustinus Andri. "Dugaan Dumping: RI Selidiki Baja Lapis Almunium Seng Asal Cina \& Vietnam.” In Bisnis.Com, 2019.

https://ekonomi.bisnis.com/read/20190828/12/1141997/dugaan-dumping-riselidiki-baja-lapis-aluminium-seng-asal-china-vietnam.

Efendi, Jonaedi. Metode Penelitian Hukum Dan Empiris. Jakarta: Kencana, 2016. "Ekspor Besi Dan Baja Menurut Tujuan Negara Utama Periode 2012-2017." In Badan Pusat Statistik, n.d. http://www.bps.go.id/staticable/2019/02/27/2033/ekspor-besi-baja-menuruttujuan-negara-utama-2012-2017.html.

Folsom, Ralph. International Bussiness Transaction. St. Paul: minn, 2000.

Grasstek, Carig Van. History and the Future of World Trade Organization. World Trade Organization, 2013.

Hartono, Sri Redjeki. Kapita Selekta Hukum Ekonomi. Bandung: Bandar Maju, 2000.

Held, David, and Anthony McGrew. Globalization Theory: Aproach and Controversies. Cambridge: Polity, 2007.

J Prausa, Thomas. "Anti-Dumping: A Growing Problem in International Trade, Vol. 28, No. 5, 2005, Hlm. 683.” The World Economy 28, no. 5 (2005): 683.

Jackson, John H. International Economic Law. EBerhart, 1997.

Kagramanto, L Budi. Mengenal Hukum Persaingan Usaha. Sidoarjo: Laras, 2015.

Kamilah, Anita. "Law Protection For Domestic Industries Due To Dumping Practice." Dinamika Hukum 15, no. 03 (2015). https://doi.org/http://dx.doi.org/10.20884/1.jdh.2015.15.3.407.

“Katalog Produk Baja Ringan Konstruksi 2018." In Direktorat Bina Kelembagaan Dan Sumber Jasa Konstruksi, Direktorat Jendral Bina Konstruksi, Kementrian Pekerjaan Umum Dan Perumahan Rakyat. Katalog Produk Baja Ringan Konstruksi 2018 (Edisi Pertama: Cetakan Pertama). Oktober 2018, 2018.

Marzuki, Peter Mahmud. Penelitian Hukum (Edisi Revisi). Jakarta: Kencana Prenadamedia Group, 2016.

Muhammad, Sadi. Hukum Persaingan Usaha Di Indonesia (Sebagai Upaya Penguatan Lembaga Komisi Pengawas Persaingan Usaha KPPU). Malang: 
p-ISSN : 2541-2345, e-ISSN : 2580-8842

Setara Press, 2016.

Nita, Anggraini. "Dumping Dalam Perspektif Hukum Dagang Internasional Dan Hukum Islam.” Mazahib Jurnal Pemikiran Hukum Islam 14, no. 2 (2015).

R, Febrina. "Dampak Kegiatan Jual Rugi (Predatory Pricing) Yang Dilakukan Pelaku Usaha Dalam Perspektif Persaingan Usaha.” Jurnal Selat 4, no. 2 (2017): 234-49.

Skousen, Mark. Teori-Teori Ekonomi Modern. Jakarta: Pernada, 2001.

Syahyu, Yulianto. Hukum Antidumping Di Indonesia. Jakarta: Ghalia, 2014.

Willems, Arnoud R, Sven De Knop, and Jeremle Charles. The Handbook of Trade Enforcement 2012 (European Commision). Global Competition Review, 2012.

"World Trade Organization Agreement about Understanding on Rules and Prosedur Governing the Settelement of Dispute (URP-GSD)," n.d.

Wu, Mark. "Antidumping in Asia's Emerging Giants." Harvard International Law Journal 53, no. 1 (2012): 9.

Young, Tan Ah. "Performance of the ASEAN Iron and Steel Industry in 2017." South East Asia Iron and Steel Institute (SEAISI), 2017. 